\title{
Program-Level Assessment of Learning Outcomes in a Faculty Certificate Program on the Scholarship of Teaching and Learning
}

\author{
Harry Hubball \& Gary Poole \\ University of British Columbia
}

\section{Introduction}

$\mathrm{O}$

$\mathrm{n}$ an international scale, higher education reform is having a profound impact on organizations and institutions, where there are now mandates and requirements to implement explicit learning outcomes and assessment policies for all undergraduate curricula (Bresciani, 2006; Hubball \& Burt, 2004; Hubball \& Burt, 2007). Program-level learning outcomes are a central component of learning-centred curricula and inform students what they can expect to achieve from a program of study so that they may organise their time and efforts, and prepare for assessments. They also connect segments of a curriculum, thus enhancing transferability of student learning, communicate curriculum/program goals in a meaningful way to a broader community, help to determine the extent to which learning has been accomplished, and guide faculty and administrators (within resource constraints), in part, to determine program(s) of study, course objectives, appropriate learning experiences, and assessment and program evaluation strategies (Barab \& Duffy, 2000; Hubball $\&$ Gold, 2007). This paper highlights program-level assessment of learning outcomes in an 8-month Faculty Certificate Program (UBC-FCP) on the scholarship of teaching and learning (SoTL) at the University of British Columbia (UBC).

\section{Program Context}

The UBC-FCP on SoTL began in 1998. UBC, Canadian, and International faculty members participated in the program to investigate critical curriculum and pedagogical issues within their department (e.g., curriculum re-design, evaluation of curricula, PBL, staff development, web-based learning), while some faculty members embark on this program for personal reasons to improve course design, teaching, learning strategies, and assessment practices. The UBC-FCP has graduated nine multidisciplinary faculty cohorts since 1999. UBC President Stephen Toope awards the Certificates to graduating faculty at Green College in May following completion of the program. Faculty graduates include national and international 
teaching award winners, CRC's, full professors, tenured faculty, tenure-tack faculty and instructors from across UBC campus (Hubball \& Poole, 2004; Hubball, Pratt, \& Collins, 2005; Hubball \& Burt, 2006; Hubball \& Albon, 2007)

The aim of the UBC-FCP is to enhance SoTL in multidisciplinary settings. Essentially, SoTL is an approach to academic work that integrates research, teaching, and learning. The literature differentiates between scholarly approaches to teaching and learning, and the scholarship of teaching and learning (Richlin, 2001; Kreber, 2001; McKinney, 2004). In the context of the UBC-FCP, the following operational definition for SoTL guides curriculum, and teaching and learning processes. Scholarly approaches to teaching and learning refer to on-going professional development, reflection, and initiation of positive changes to curricula and/or pedagogical practices. Taking this concept to the next level of rigour, SoTL refers to the dissemination of practice-driven curricula andlor pedagogical research in peer-review contexts.

\section{Action Research and Program-level Assessment of Learning Outcomes}

Action research (AR) methodology is at the very heart of SoTL. In this context, AR was employed to strengthen the underlying theory/rationale for learning experiences within a program, and gain authentic data on which to (cyclically) reflect on the effectiveness of processes and outcomes (Altrichter, Psch, \& Somekh, 1993; Hubball \& Clarke, 2004; Hubball \& Levy, 2004; Wolfe, Hill, \& Evers, 2006). Action research methodology was employed to address four specific research questions pertaining to programlevel assessment of learning outcomes:

1 What are the critical factors when developing program-level learning outcomes?

2 To what extent are learning outcomes reflected in program learning experiences?

3 When and how do faculty members demonstrate learning outcomes in this context?

4 What are the overall reflections for implementa- tion of program-level learning outcomes in this context?

The following data were gathered to address the above research questions: a critical review of faculty members' SoTL portfolios; program literature sources from the website and curriculum materials; cohort members' program evaluation feedback pertaining to the quality of program, teaching and learning experiences; focus group interviews with cohort members' video footage of research presentations; and instructors' debrief and review of lecture notes.

\section{Results}

\section{1) What are the critical factors when developing program-level learning outcomes?}

The following framework and critical elements guided the development and implementation of programlevel learning outcomes:

Learning context strategies. This refers to a comprehensive needs assessment which was conducted by consulting with various sources (e.g., a focus group of UBC faculty members from various academic ranks and disciplines who were committed to the SoTL and willing to participate in a pilot-program) to guide the development of program-level learning outcomes.

Planning strategies. This refers to the logistics of program scheduling, as well as the development of explicit core program-level learning outcomes; i.e., in the context of the SoTL, UBC-FCP faculty will demonstrate: 1) the acquisition, application and integration of SoTL knowledge; 2) research skills, including the ability to define problems and access, retrieve and evaluate SoTL information; 3) a critically reflective practice and problem-solving abilities with respect to SoTL; 4) responsible use of ethical principles; and 5) effective leadership, communication, and interpersonal skills (Table 1 shows how specific learning outcomes relate to UBC-FCP learning experiences). 


\section{Table 1}

\begin{tabular}{|c|c|}
\hline $\begin{array}{l}\text { UBC-FCP Learning } \\
\text { Experiences and } \\
\text { Program-level Learning } \\
\text { Outcomes }\end{array}$ & Evidence of Learning in UBC-FCP \\
\hline $\begin{array}{l}\text { External Peer-review and } \\
\text { Record of Progress (1-5) }\end{array}$ & $\begin{array}{l}\text { Through question and answer format, the external assessor examines the can- } \\
\text { didate's understanding of SoTL concepts and to what extent these have been } \\
\text { applied in classroom and curricula practices. }\end{array}$ \\
\hline Teaching Dossier (1-5) & $\begin{array}{l}\text { E-portfolio/Written evidence of teaching philosophy, as well as contributions, im- } \\
\text { pact, and assessment of teaching practices. Integration of SoTL literature sources } \\
\text { within text. }\end{array}$ \\
\hline Teaching $\log (3,5)$ & $\begin{array}{l}\text { Weekly written evidence of teaching reflections pertaining to what has been } \\
\text { learned, analysis summary, and implications for further classroom practices and } \\
\text { further learning. }\end{array}$ \\
\hline $\begin{array}{l}\text { Learning-centred Course } \\
\text { Syllabus }(1,4,5)\end{array}$ & $\begin{array}{l}\text { Documentation of clearly presented syllabi with course learning outcomes and } \\
\text { integrated assessment, evaluation, broader curriculum concepts, references, and } \\
\text { tentative schedule/course format. }\end{array}$ \\
\hline $\begin{array}{l}\text { Action Research: Peer- } \\
\text { Review of Teaching } \\
\text { Practices }(1-5)\end{array}$ & $\begin{array}{l}\text { Written documentation of lecture planning, peer-review criteria, observer's feed- } \\
\text { back, and a reflective statement pertaining to what has been learned, analysis } \\
\text { summary, and implications for further classroom practices and further learning. }\end{array}$ \\
\hline SoTL Interview (2-5) & $\begin{array}{l}\text { Written evidence of research questions, data responses, and a reflective state- } \\
\text { ment pertaining to what has been learned, analysis summary, and implications for } \\
\text { classroom practices and further learning. }\end{array}$ \\
\hline $\begin{array}{l}\text { Self-Directed Learning } \\
\text { Project (1-5) }\end{array}$ & $\begin{array}{l}\text { Written evidence of a publishable paper/SoTL proposal for conducting classroom/ } \\
\text { curriculum research. Includes literature review, research questions, research } \\
\text { methodology, implications for study results, references, and dissemination plans. }\end{array}$ \\
\hline $\begin{array}{l}\text { Pedagogical Research } \\
\text { Presentation (1-5) }\end{array}$ & $\begin{array}{l}\text { Visual and written evidence of conference presentation pertaining to a SoTL } \\
\text { research project. Includes abstract, literature review, research questions, research } \\
\text { methodology, implications for study results, and references. }\end{array}$ \\
\hline
\end{tabular}

Assessment strategies. This refers to the implementation of a wide range of assessment methods (e.g., self-reflection, peer-feedback, instructor feedback, and external peer-review) to assess program-level learning outcomes.

Programming strategies. Depending on Prior Learning Assessment (PLA), each faculty participant in this FCP context follows an individual learning plan which combines theory, practice, and critical reflection. Guided by the program-level learning outcomes, faculty participants have on-line weekly assignments, as well as a meeting each month, and at different locations on campus to engage in a wide range of independent and/or collaborative learning experiences.

\section{2) To what extent are learning outcomes} reflected in program learning experiences?

A faculty member's SoTL portfolio is a compilation assignment used to demonstrate how program-level learning outcomes (listed above) feature in a wide range of authentic learning experiences. Table 1 captures the range of UBC-FCP learning experiences that are employed to address the five UBC-FCP program-level learning outcomes.

\section{3) When and how do faculty members demonstrate learning outcomes in this context?}

For example, feedback on a faculty member's teach- 
ing dossier is provided at four key incremental stages throughout the 8-month program. Further, an external review takes place at the 40 and 60 percent (informal formative feedback provided toward each SoTL assignment within the faculty member's portfolio) stages of the program, as well as during the final month (formal summative process) of the 8-month program. In the context of a wide range of UBCFCP learning experiences, this not only allows for progressive development of each assignment within the SoTL portfolio, it also staggers the completion deadlines for overall SoTL assignments and demonstration of program-level learning outcomes.

\section{4) What are the overall reflections for implementation of program-level learning outcomes in this context?}

The flexibility, quantity, and quality of overall program-level learning outcomes are critical issues when shaping teaching, learning, and assessment experiences. In many cases, learning experiences integrated multiple and overlapping program-level learning outcomes. This was not viewed as excessive, redundant, or repetitive, but rather an indication that program-level learning outcomes can be interpreted in different ways and demonstrated in many authentic ways. Too many program-level learning outcomes, however, can create surface learning rather than deep and meaningful learning. Not all faculty members were aware of the implicit connections between program-level learning outcomes and program experiences. Furthermore, a number of faculty members were unsure about the priority of program-level learning outcomes over personal and alternative outcomes. Thus, the development and implementation of program-level learning outcomes is not an exact science. Furthermore, programs involve complex, multifaceted, and contextually-bound program realities and are influenced by many people at various levels of implementation.

\section{Conclusion}

Universities and academic units face considerable challenges in developing, adopting, and implement- ing program-level learning outcomes within university curricula. Despite well-coordinated, innovative, and strategic attempts to implement program-level learning outcomes, they are unlikely to fully occur as intended due to the highly complex world of curriculum practice.

This article provides a flexible and iterative framework to examine whether and how programlevel learning outcomes are implemented in a faculty certificate program. Data from this study suggest that educational leadership, learning context, planning, programming and assessment processes were critical factors in the development and implementation of program-level learning outcomes.

\section{References}

Altrichter, H., Psch, P., \& Somekh, B. (1993). Teachers investigate their work: An introduction to the methods of action research. London, England: Routledge.

Barab, S.A., \& Duffy, T. (2000). From practice fields to communities of practice. In D. Jonassen \& S.M. Land (Eds.), Theoretical foundations of learning environments (pp. 25-56). Mahwah, NJ: Erlbaum Associates.

Bresciani, M.J. (2006). Outcomes-based academic and co-curricular program review. Sterling, VA: Stylus Publishing, LLC.

Hubball, H.T., \& Albon, S. (2007). Developing a faculty learning community: Enhancing the scholarship of teaching, learning and curriculum practice. Journal on Excellence in College Teaching.

Hubball, H.T., \& Gold, N. (2007). The scholarship of curriculum practice and undergraduate program reform: Theory-practice integration. In P. Wolfe \& J. Christensen Hughes (Eds.), Curriculum development in higher education: Faculty-driven processes \& practices. New Directions for Teaching and Learning, 112, 5-14. San Francisco: Jossey-Bass Publishers. 
Hubball, H.T., \& Burt, H.D. (2007). Learning outcomes and program-level evaluation in a 4-Year undergraduate pharmacy curriculum. American Journal of Pharmaceutical Education, 71(5), Article 90, 1-8.

Hubball, H.T., \& Burt, H.D. (2006). Scholarship of teaching and learning: Theory practice integration in faculty certificate programs. Innovative Higher Education, 30(5), 327-344.

Hubball, H.T., Pratt, D.D., \& Collins, J. (2005). Investigating changes in teaching perspectives for faculty enrolled in the UBC Faculty Certificate Program on teaching and learning in higher education. Canadian Journal of Higher Education, 35(3), 57-81.

Hubball, H.T., \& Poole, G. (2004). A learning-centred course on university teaching. International Journal for Academic Development. 8(2). 11-24.

Hubball, H.T., \& Clarke, A. (2004). Assessing faculty learning communities. In M.D. Cox \& L. Richlin (Eds.), Building faculty learning communities, (pp. 87-100), New directions for teaching and learning, 97. San Francisco, CA: Jossey-Bass.

Hubball, H.T., \& Levy, A. (2004). Graduate course design in health care and Epidemiology: A learning-centred approach. Journal for Faculty Development, 20(1).

Hubball, H.T., \& Burt, H.D. (2004). An integrated approach to developing and implementing learning-centred curricula. International Journal for Academic Development, 9(1), 51-65.

Kreber, C. (2001). Conceptualizing the scholarship of teaching and identifying unresolved issues: The framework for this volume. In C. Kreber (ed.), Scholarship revisited: Perspectives on the scholarship of teaching, (pp. 1-18), New directions for teaching and learning, 86. San Fran- cisco, CA: Jossey-Bass.

McKinney, K. (2004). The scholarship of teaching and learning: Past lessons, current challenges, and future visions. In C. Wehlburg \& S. Chadwick-Blossey (Eds.), To improve the academy, resources for faculty, instructional, and organizational development, 22, (pp. 3-19). Bolton, MA: Anker.

Richlin, L. (2001). Scholarly teaching and the scholarship of teaching. In C. Kreber (Ed.), Scholarship revisited: Perspectives on the scholarship of teaching (pp. 57-68), New directions for teaching and learning, 86. San Francisco, CA: Jossey-Bass.

Wolfe, P., Hill, A., \& Evers, F. (2006). A handbook for curriculum assessment. University of Guelph Publications, Ontario. 